\title{
Earthcomm-based Multimedia Learning of Geography in Improving Learning Motivation and Spatial Ability of the High School Students
}

\author{
Achmad Nur Hidayaht ${ }^{1}$, Sarwono $^{2}$, Yasin Yusup ${ }^{3}$ \\ ${ }^{123}$ Sebelas Maret University, Ir. Sutami 36A, Surakarta, Indonesia. (57126)
}

\begin{abstract}
This research aimed to analyze the needs of EarthComm-based learning multimedia of geography, the effectiveness of the multimedia to improve students' motivation and spatial ability; and analyze the feasibility of multimedia utilization in two public high schools in Surakarta by using ADDIE development model. The data of learning multimedia needs were collected by distributing questionnaires to the targeted correspondents ( 2 teachers and 30 students). Meanwhile, regarding the effectiveness of the multimedia in improving students' spatial ability and motivation, the data were collected by utilizing Spatial Thinking Ability Test (STAT) and questionnaires. The assessment of feasibility was done by distributing experts' validation sheet and students' assessment. The data analysis tool used was one-way ANOVA. The result of the need analysis shows that $>75 \%$ of students have medium level of motivation, $>90 \%$ of students have low spatial ability, and $>80 \%$ of the students need a more innovative geography lesson. After implementing EarthComm-based geography multimedia learning, it is known that the multimedia is effective to improve the students' motivation and spatial ability which is shown by the significance value gained $(0.00<0.05)$. Furthermore, based on the experts' judgment and small-scale trials done, it is concluded that the EarthComm-based geography multimedia learning is feasible to be implemented.
\end{abstract}

Keywords: EarthComm; Geography; Multimedia; Motivation; Technology; Spatial Ability.

\section{INTRODUCTION}

Education is one of the indicators that shows the quality of life related to human development index (HDI) [1]. In its function as an indicator of HDI, education is oriented on the effort to make a knowledgeable nation. Hence, for a country, having a good quality of education is an obligation. One of the efforts to improve the quality of education is by utilizing the sophistication of information technology. One of the manifestations of such sophistication is in the form of learning multimedia. Benefitting such platform, efficiency and quality of education can be improved.

Munir (2013) states that multimedia has advantages in learning. One of which is to facilitate the delivery of learning metrics such as showing objects that cannot be seen directly and bringing a difficult object into the learning environment [2]. As what Robblyer, M \& Doering (2010) proposed that multimedia is aimed at communicating 
information in multiple ways, the multimedia can be wrapped in a product consisting of graphics and photographs, sound, motion video, animation, and/or text items [3]. In another similar idea Vaughan (2011) states that multimedia is sent to the recipient via electronic or digital equipment such computers, the multimedia consists of combination of various things including text, images, sound, animation and video [4].

In the context of geography learning, the utilization of multimedia is also very beneficial as it is one of the subjects taught at the high school. Hubbard P., Kitchin R., and Bartley B (2005) suggest that geography studies the spatial relationships between earth and humanity through the study of places, spaces, and environments [5]. Based on the idea, it hard for the students if they have to go outside the classroom to see directly the place or object being studied. Hence, regarding the needs, multimedia is a way of solution as it, with its potential, can bring the objects or places being studied to classroom in the form of images, videos, or in a form of more complex and detail platform such as adobe flash.

In addition to the benefit mentioned above, multimedia also has the potential to improve students' motivation and spatial ability. This is very crucial since the two (motivation and spatial ability) can influence the success of geography learning. According to Sudjana (2014) the process of success in teaching and learning activities (including geography) can be seen in the motivation to learn that can be demonstrated by the learners at the time of learning activity [6]. Furthermore, Mudjiman (2011) also said that learning motivation can drive force and direct the learning actions[7]. According to Gafur (2012) motivation is an incentive come from within the learner (intrinsic) or from outside the learner (extrinsic)[8]. In line with Gafur, Uno (2014) reveals that an intrinsic drive takes the form of desire and wish to succeed, the impulse of learning needs; and hope of aspiration, meanwhile, the extrinsic factor takes the form of appreciation of a conducive learning environment and interesting learning activities [9]. In geography lessons motivation can be improved by bringing material that is in the student environment into learning activities.

Regarding the spatial ability, it is an element in geography learning which plays a role to help learners to understand the material geography contextually and to implement what is learned in school with real life in order to understand the geographical conditions of the environment around their residence. Huynh (2009) proposed that spatial ability is the capability to perform three mental skills, orientation, spatial relation and spatial visualization [10]. Another similar idea was also stated by Association of American Geographies (2008) which defines spatial ability as the ability to analyze and visualize spatial relationships between objects such as location, distance, direction, shape, and pattern [11]. Those ideas are in line with Cesar, A. and Gaible, E, (2014) who state that education is not only aimed to transfer knowledge, but also improve the ability of analysis, synthesis, communication and connecting science to the real world[12]

Related to the importance of motivation and spatial ability, in the geography learning there is a concept of EarthComm model which also can address the two essential elements. Smith, Gosselin, Robeck (2001) define four key concepts drove the development of EarthComm instructional design. The first is Relevance an understanding of where, when, and how of a process or event. Second is Community, which in essence, is a group of varied living things interacting in some ways, the idea of community overlaps with the geographic concept of regions, because living things (biotic factors) are affected by and affect non-living things (abiotic factors) making the 
physical setting important. The third is Inquiry meaning central to advancing personal and collective scientific knowledge. The last is System, Earth system is like a living system and everything is connected to everything else [13]. EartComm promotes an understanding of spatial assessment to learners through the concepts of relevance, community, inquiry and systems through geography learning, in other words geography learning with the EarthComm model is one form of learning to think and practice spatial skills. Dabling (2007) explains that the activities in each chapter of EarthComm introduce relevant events, scenarios, and real-life challenges that are pertinent to the student's everyday life, In doing so emphasizes significant abilities concepts and understandings that are enable students to think critically, understand, appreciate the Earth system, and make informed decisions[14].(Park, DY. Smith, M. Yeager (2005) states that EarthComm learning has chapters linked to a broader theme, each chapter starting with contextual issues in society or issues that can only be overcome by developing ideas, key and understanding in learning activities [15]. By bringing environmental issues around the students into learning activities, students will be more enthusiastic and motivated to be more familiar with the condition in the environment and surrounding areas. By bringing such condition, it also, then, can stimulates students' spatial ability.

Related to the issues of learning multimedia, EarthComm, and spatial ability, there are plenty of researches have been done before. Two of the researches was done by Suherdiyanto (2009) [16] and Hanifah (2015) [17] who implemented EarthComm learning to improve learning achievement. The other similar researches were also done by Dewi (2011) [18] and Wahyuningsih (2014) [19] who tested the influence of EarthComm towards students' critical thinking. Hidayaht (2015) also done a research which tested the effectiveness of EarthComm in improving students' learning achievement viewed from their level of motivation [20]. The next researches were done by Muryani.C, Nugraha, and S. Soegiyanto (2016) [21] and Istifarida. B (2016) [22] who develop learning multimedia in the form of video and e-book.

Those researches can be considered contributing to the development related to the issues. However, they cannot fully address the beneficial points of the three elements being discussed (multimedia, spatial ability, and EarthComm) even some of them tends to jump to a conclusion by relating EarthComm directly to learning achievement, whereas, there are plenty of factors (internal and/or external) which can influence the improvement of learning achievement. Hence, considering the potential of multimedia and the importance of EarthComm concept of learning model in stimulating and improving motivation and spatial ability, it is very essential to develop a platform of learning supportive tools in the form of EarthComm-based geography learning multimedia as what has been done in this study.

\section{METHODS}

This research is designed in the light of Research and Development model which carried out with ADDIE model. Mcgriff (2000) explains that ADDIE is an instructional model that uses systematic approach to the Analysis, Design, Development, Implementation, and Evaluation of learning materials and activities [21].

The research was conducted in two public high schools in Surakarta (SMA MTA and $M A N 2)$ which started by preliminary research (15-24 march 2017), then, was continued with the process of designing the multimedia (April-Mei 2017). The data needed for 
testing the efficiency of the multimedia toward the improvement of students' motivation and spatial ability were collected by using questionnaires and spatial ability test (STAT) by Lee \& Bednarz (2012) [24] who was develop hierarchical set of spatial ability concepts based on Golledge (2002) [25] and Gersmehl (2005) [26].

TABLE I.DESCRIPTION OF SPATIAL ABILITY QUESTION COMPONENTS TO MEASURE.

\begin{tabular}{|c|c|c|}
\hline Type & Item Description & $\begin{array}{c}\text { Spatial Thingking Ablity Component To } \\
\text { Measure }\end{array}$ \\
\hline 1 & 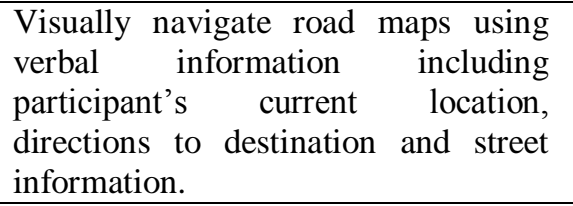 & $\begin{array}{l}\text { Assesses the trait of "understanding } \\
\text { orientation and direction (eg left-right, up- } \\
\text { down, } \\
\text { north/south/east/west)"(Golledge 2002). }\end{array}$ \\
\hline 2 & $\begin{array}{l}\text { ecognize map patterns and represent } \\
\text { em in graphic form. }\end{array}$ & $\begin{array}{l}\text { Evaluate the trait of "spatial patterns form and } \\
\text { graphing a spatial transition" (Gersmehl 2005). }\end{array}$ \\
\hline 3 & $\begin{array}{l}\text { Recognizing on multiple pieces of } \\
\text { spatial information such as land use, } \\
\text { elevation, population density. etc to } \\
\text { choosing an ideal location for a } \\
\text { fictitious facility. }\end{array}$ & $\begin{array}{l}\text { Evaluate the trait inferring a spatial aura } \\
\text { (influence)" (Gersmehl 2005) and } \\
\text { "comprehending overlay and dissolve" } \\
\text { (Golledge 2002)" }\end{array}$ \\
\hline 4 & $\begin{array}{l}\text { Create a profile of topography along a } \\
\text { proposed line on a contour map. In } \\
\text { addition, the participants need to } \\
\text { properly orient themselves in situ. }\end{array}$ & $\begin{array}{l}\text { "Identify spatial form and being able to } \\
\text { transform perceptions and representations" } \\
\text { (Golledge 2002) and "graphing a spatial } \\
\text { transition" (Gersmehl 2005). }\end{array}$ \\
\hline 5 & $\begin{array}{l}\text { Display the identified spatial } \\
\text { relationship in a graphic form through } \\
\text { Identify spatial correlations between } \\
\text { sets of maps. }\end{array}$ & $\begin{array}{l}\text { Assesses the trait "understanding and assessing } \\
\text { spatial association (positive and negative)" } \\
\text { (Golledge 2002), "making a spatial } \\
\text { comparison" (Gersmehl 2005). }\end{array}$ \\
\hline 6 & $\begin{array}{l}\text { Mentally visualize a 3-D image based } \\
\text { on 2-D information and reverse. }\end{array}$ & $\begin{array}{l}\text { Correspond the trait of "being able to } \\
\text { transform perceptions, representations and } \\
\text { images from one dimension to another and the } \\
\text { reverse" (Golledge 2002). }\end{array}$ \\
\hline 7 & & $\begin{array}{l}\text { Evaluate to the trait "overlaying and dissolving } \\
\text { maps" (Golledge 2002). }\end{array}$ \\
\hline 8 & $\begin{array}{l}\text { Visually recognizing information data } \\
\text { on maps or imagery, such as shapes, } \\
\text { patterns and try to represent } \\
\text { information to spatial data. }\end{array}$ & $\begin{array}{l}\text { "Figure out integration of geographic features } \\
\text { represented as points, networks, and regions" } \\
\text { (Golledge 2002) and "comprehending spatial } \\
\text { shapes and patterns" (Golledge 2002). }\end{array}$ \\
\hline
\end{tabular}

Source: (Lee \& Bednarz, 2012)

There were 73 subjects used (40 students from SMA MTA as experimental group and 33 students from MAN 2 as control group) which were chosen by using cluster random sampling technique. The experimentation of multimedia effectiveness and feasibility was carried out on June 2017 by using pretest - posttest design. The data gained, then, were analyzed by using one-way ANOVA with the significance value of 0.05 . 


\section{RESULT AND DISCUSSION}

\section{Result of Need Analysis, Effectiveness, and the Feasibility of the Multimedia}

Multimedia development firstly begins with Analysis stage consisting of performance and need analysis. The result of the analysis stage was to propose some points as follows:

a) The results of interviews with geography teacher shows that the learning media usually used is the power point and some even rarely use the learning media.

b) The results of questionnaires from students show (>80\%) feel bored in learning and the students' expectation of innovative and interesting learning activities

c) The middle quantity of students' motivation $(>75 \%)$, while, low spatial ability of learners is $(>90 \%)$.

d) From curriculum analysis, it was also found out that the time limit in explaining course material of hydrosphere.

Thus, based on the findings, it can be concluded that innovative and interesting multimedia learning on hydrosphere subject is badly needed.

Second is the Design stage. It started by formulating the framework of the instructional objectives and material points; creating criteria of success; and writing the multimedia script framework which consists of storyboard, flowchart, background, backsound, layout, image, animation, video. The stage, then, were continued to the Development stage in which the outline flowchart, storyboard, materials, audio and video graphics are blended into a learning multimedia.

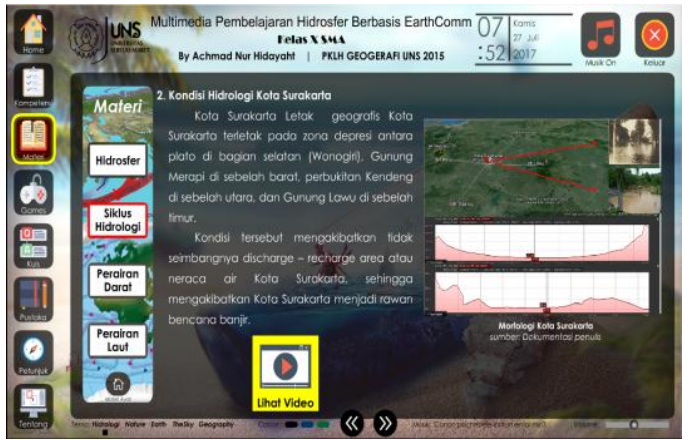

Figure 1. Example of text provided in the multimedia

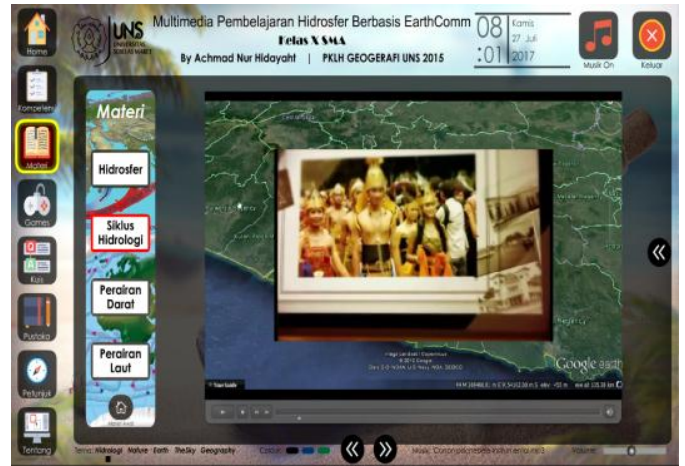

Figure 3. Example of video provided in the multimedia

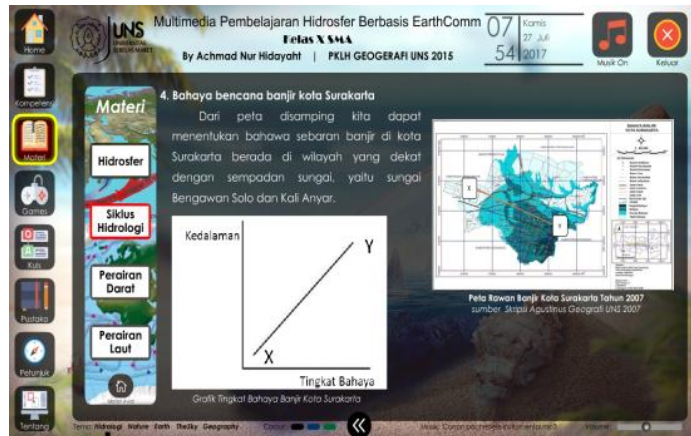

Figure 2. Example of picture provided in the multimedia

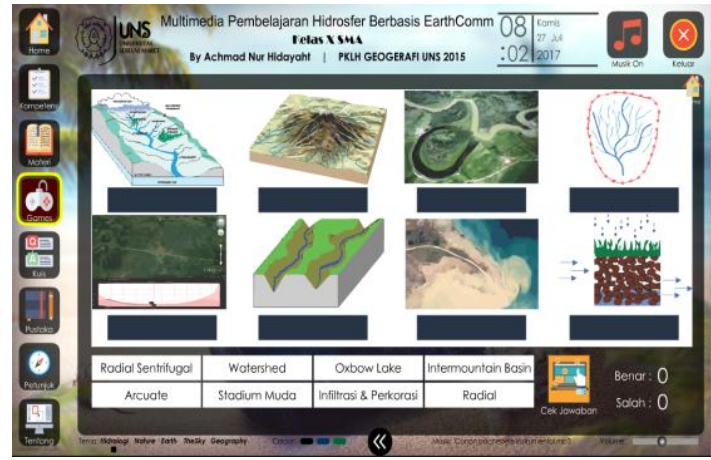

Figure 4. Example of quiz provided in the multimedia 
After the learning multimedia formed, the next step done was validating the multimedia. The fourth step/stage of the multimedia development was implementation phase that included one to one evaluation, small group evaluation, and field trial evaluation. The last stage is the Evaluation; experimental results based on evaluations that have been implemented obtained the following data:

TABLE II. LEARNING MOTIVATION DATA OF STUDENTS'

\begin{tabular}{ccccc}
\hline & \multicolumn{4}{c}{ Class } \\
\cline { 2 - 5 } & \multicolumn{2}{c}{ X IPS 2(co) } & \multicolumn{2}{c}{ X IPS 4(ex) } \\
\cline { 2 - 5 } Average & Pre-Test & Post-Test & Pre-Test & Post-Test \\
\hline Sum & 108.52 & 113.88 & 111.73 & 123.85 \\
& 3581 & 3758 & 4469 & 4954 \\
\hline
\end{tabular}

TABLE III. SPATIAL ABILITY DATA OF STUDENTS'

\begin{tabular}{ccccc}
\hline & \multicolumn{3}{c}{ Class } \\
\cline { 2 - 5 } & \multicolumn{2}{c}{ X IPS 2(co) } & \multicolumn{2}{c}{ X IPS 4(ex) } \\
\cline { 2 - 5 } Average & Pre-Test & Post-Test & Pre-Test & Post-Test \\
Sum & 43.79 & 70.76 & 46.69 & 84.38 \\
\hline
\end{tabular}

Information $\quad: \mathrm{ex}=$ Experimental Class $\mathrm{co}=$ Control Class

Class $\quad:$ XIPS 2 on SMA MAN 2 Surakarta

: XIPS 4 on SMA MTA Surakarta
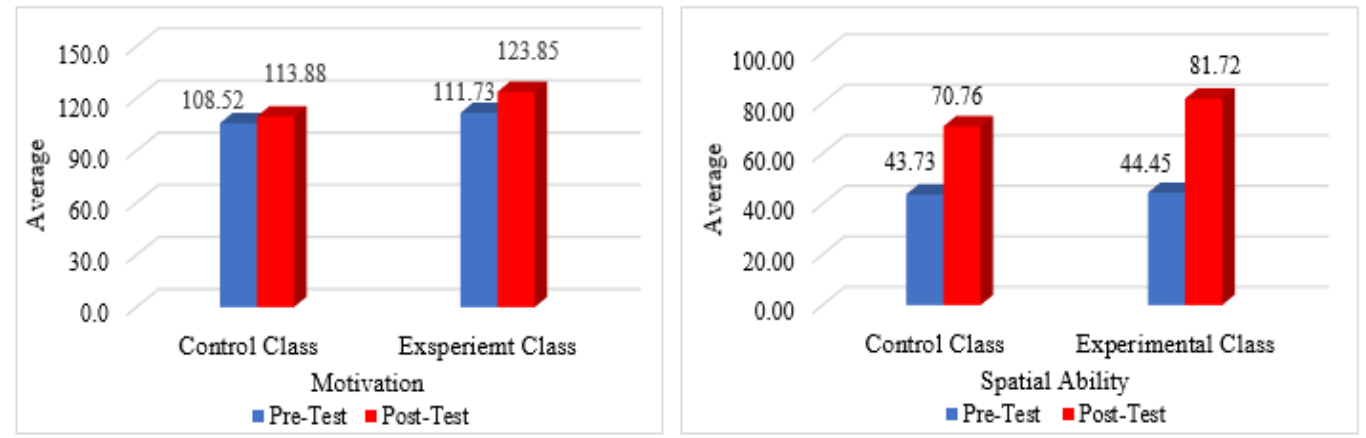

Figure 5. Average Graph of Spatial Ability and Students’ Motivation

The results of data analysis prove the positive impact of EarthComm-based geographic learning multimedia on the students' learning motivation and spatial ability compared to power point media. 
TABLE IV ANALYSIS OF VARIANCE (ONE-WAY ANOVA) STUDENT MOTIVATION

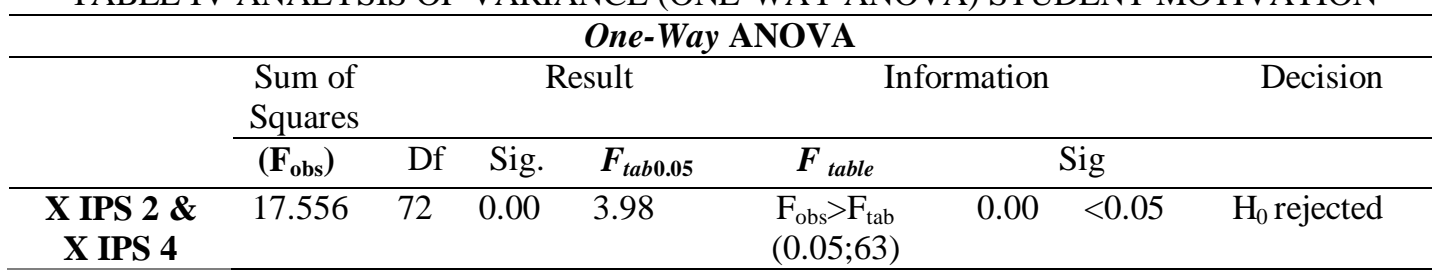

TABLE V. ANALYSIS OF VARIANCE (ONE-WAY ANOVA) SPATIAL ABILITY OF STUDENTS

\begin{tabular}{ccccccccc}
\hline & \multicolumn{7}{c}{ One-Way ANOVA } \\
\hline & $\begin{array}{c}\text { Sum of } \\
\text { Squares }\end{array}$ & \multicolumn{2}{c}{ Result } & \multicolumn{2}{c}{ Information } & Decision \\
\cline { 2 - 9 } & $\left.\mathbf{F}_{\text {obs }}\right)$ & Df & Sig. & $\boldsymbol{F}_{\text {tab0.05 }}$ & $\boldsymbol{F}_{\text {table }}$ & Sig & \\
\hline X IPS 2 \& & 44.93 & 72 & 0.00 & 3.99 & $\mathrm{~F}_{\text {obs }}>\mathrm{F}_{\text {tab }}$ & 0.00 & $<0,05$ & $\mathrm{H}_{0}$ rejected \\
X IPS 4 & & & & & $(0.05 ; 63)$ & & \\
\hline
\end{tabular}

As can be clearly seen in the table above, the value of $F_{o b s}$ is higher than $F_{t a b}$ indicating the significance difference. Furthermore, from the mean score, the experimental class gets higher score than the control class. Thus, it can be concluded that the implementation of EarthComm-based geography multimedia learning result is more effective in improving students' motivation and spatial ability than power point media.

The next point of the data result that will be elucidated is the positive impact on the students' learning motivation and spatial ability related to the assessment of the developed multimedia based on the implementation in one to one evaluation, small group evaluation, field trial evaluation, and expert validation. Both of the implementation and expert validation are used as a revision to multimedia improvement. The data of multimedia feasibility were acquired from field trial and external validation is as follows:

TABLE VI. SCORE MODES AND AVERAGE MULTIMEDIA VALIDATION

\begin{tabular}{clcc}
\hline No. & Validation and Assesment & Modes & Average \\
\hline 1. & Material Expert Validation & 4 & 4.24 \\
2. & Media Expert Validation & 4 & 4.25 \\
3. & Educator Validation & 4 & 4.40 \\
4. & One to One Evaluaion & 5 & 4.83 \\
5. & Small Group Evaluation & 5 & 4.57 \\
6. & Field Trial Evaluation & 4 & 4.34 \\
\hline
\end{tabular}

According to the assessment result, it can be clearly stated that Earthcomm-based geography learning multimedia and its impact on life is feasible to be used in learning those schools as it gets the mode score of 4 (considered as good in likert scale). The feasibility of the product in this study is only in a limited-scale trial in schools that are used as research so that further research is needed in relation to dissemination and implementation in general or in a broader scope. 


\section{Discussion}

Analyses of the data by one-way Anova found that the immersive EarthCommbased geography multimedia learning support significantly students' learning motivation and spatial ability. This finding is in line with Hidayaht (2015) [20] stated that the implementation of EarthComm learning can improve students' motivation. The result is also in line with the statement says that EarthComm's learning emphasizes concepts and abilities that enable learners to think critically about their environment issues that make learning more interesting. EarthComm initiates learning activities by presenting contextual issues around the environment of students', EarthComm's application in learning provides an opportunity for learners to develop their optimallyowned potential with a pleasant classroom atmosphere. Application video used in multimedia that visualizes their areas will make learning activities more psychologically appealing and keep the learners' attention centered on the material presented in the learning activities. Learners will be stimulated and motivated to further develop their ideas and ideas about what they know about their environment.

In addition to improving motivation, the implementation of EarthComm-based geography learning multimedia also improves students' spatial ability; EarthCommbased multimedia that visualizes real-world conditions helps students understand their environment, making it easier for students to float their spatial abilities. These findings are reinforced by [21] saying that students taught using learning multimedia had a better spatial ability than those who were taught conventionally.

Several publication about the improvement of spatial ability skills through using media has done by [27] who was using GIS media to inprove students' spatial ability, she argues that there is a relationship between GIS media learning levels and the level of spatial thinking, a higher GIS learning level which means more GIS learning achieved, leads to better spatial abilities achieved by the students [27], Similar things are revealed by [28] and [22] who saw media as an instructional tool to support spatial thinking in other geography courses and media is an effective means to improve student comprehension of map symbols and geographic data types. From the present findings it can be concluded that the media/multimedia was very beneficial for improve students' motivation and spatial ability.

\section{CONCLUSION}

Based on the elucidation above, several conclusions could be drawn as follows:

a. From the needs analysis done to teachers and students' in MAN 2 and SMA MTA Surakarta, regarding EarthComm-based geography learning multimedia show that $>75 \%$ of students have medium level of motivation, $>90 \%$ have low level of spatial ability, and $>80 \%$ feel bored in learning and need a more innovative geography lesson.

b. The implementation of EarthComm-based geography learning multimedia is more effective to improve students' learning motivation and creates more interesting learning activities. More precisely, the experimental class gets higher motivation (123.85) than control class (113.88).

c. The implementation of EarthComm-based geography learning multimedia is more effective to improve students' spatial ability in the subject of hydrosphere. 
Regarding tehe spatial ability test result, the experimental class gets higher spatial ability (84.38) than control class (70.76).

d. The validation and assessment results obviously show that EarthComm-based geography learning multimedia is feasible and eligible to be implemented as media of geography learning in limited scale. Therefore, further research is needed in relation to dissemination and implementation in general or in a broader scope.

\section{ACKNOWLEDGEMENT}

Special thanks to the both of Headmasters of MAN 2 Surakarta and SMA MTA Surakarta who gave permission to conduct research, and also all the teachers and students who had involved in this research.

\section{REFERENCE}

[1] Badan Pusat Statistik. (2015). Indeks Pembangunan Manusia 2015. Indonesia: Badan Pusat Statistik. Retrieved

[2] Munir. (2013). Multimedia konsep dan Aplikasi dalam Pendidikan. Bandung: Alfabeta.

[3] Robblyer, M \& Doering, A. (2010). Integrating Educational Technology Into Teaching. Boston: Pearson.

[4] Vaughan, T. (2011). Multimedia: making it work (8thed). New York: McGraw-Hill.

[5] Hubbard P., Kitchin R., Bartley B., E. a. (2005). Thinking geographically: space, theory, and contemporary human geography. London: Continuum.

[6] Sudjana, N. (2014). Penilaian Hasil Proses Belajar Mengajar. Bandung: PT Remaja Risadakarya.

[7] Mudjiman, Haris. (2011). Belajar Mandiri: Pembekalan dan Penerapan. Surakarta: UNS Press.

[8] Gafur, A. (2012). Desain Pembelajaran: Konsep, Model dan Aplikasinya Dalam Perencanaan Pelaksanaan Pembelajaran. Yogyakarta: Ombak

[9] Uno, H. (2014). Teori Motivasi Dan Pengukuranya, Analisis di Bidang Pendidikan. Jakarta: PT Bumi Aksara.

[10] Huynh, N.T. (2009). The Role of Geospatial Thinking and Geographic Skills in Effective Problem Solving with GIS: K-16 Education. Tesis. Wilfrid Laurier University

[11] Association of American Geographies. (2008). Introducing spatial thinking skiils cross the curriculum. Washington, DC: AAG.

[12] Cesar, A. and Gaible, E. (2014). Development of Multimedia Material : Second Edition, 95-117

[13] Smith, MJ. Gosselin, D. Robeck, E. (2001). EarthComm Teacher Enchancement Workshop Manual. America: American Geological Institute

[14] Dabling, M. (2007). Profile In Science "EarthComm” (2nd ed.). Colorado Spring: BSCS.

[15] Park, DY. Smith, M. Yeager, R. (2005). Implementing EarthComm: Teacher Professional Development and Its Impact on Student Achievement Scores in a Standards-Based Earth Science Curriculum. Journal of Science Education, 9(March), 1-20.

[16] Suherdiyanto. (2009). Uapaya Peningkatan Hasil belajar siswa Melalui Pembelajaran Earth Science Community (Earthcomm). Jornal. STKIP-PGRI Pontianak

[17] Hanifah, P, M (2015). Penerapan Model Pembelajaran Sets Dan Earthcomm Untuk Meningkatkan Kemampuan Berpikir Kritis Peserta Didik. Skripsi. Universitas Sebelas Maret: Surakarta

[18] Dewi, A.I (2011). Pengaruh Pendekatan Earth Science Community (Earthcomm) Dan Pembelajaran Berbasis Masalah Terhadap Kemampuan Berpikir Kritis Peserta Didik.Tesis. Universitas Pendidikan Indonesia: Bandung

[19] Wahyuningsih. M.P (2014). Pengaruh Penerapan Model Pembelajaran Earth Science System in The Community (EarthComm) Terhadap Kemampuan Berpikir Kritis Kelas X MAN Malang II Batu. Jurnal Pendidikan Geografi. Universitas Malang. 
[20] Hidayaht, A N. (2015). The Effectiveness Of The Use Of Earth Science Community (Earthcomm) Learning Model Assisted With Google Earth Concerning To The Result Of Geography Learning Outcomes Viewed From Students' Learning Motivation. Essay. Sebelas Maret University: Surakarta

[21] Muryani, C., Nugraha, S., Soegiyanto, H., \& City, B. (2016). Developing Learning Multimedia Based On Geographical Information System To Improve Students ' Spatial Ability In FloodDisaster Mitigation, 1, 345-349.

[22] Istifarida, Binti. (2017). Pengembangan E-Book Berbasis Problem Based Learning-GIS Untuk Meningkatkan Kecakapan Berfikir Keruangan Pada Siswa Kelas X SMA N 1 Sragen 2016/2017. Prosiding Seminar Nasional Geotik 2017. Issn:2580-8796 : Universitas Muhamadiyah Surakarta

[23] McGriff, S. J. (2000). Intructional System Desaign (ISD): Using the ADDIE Model, Intrutional System. College of Education, Penn State

[24] Lee, J., \& Bednarz, R. (2012). Components of Spatial Thinking: Evidence from a Spatial Thinking Ability Test. Journal of Geography, 111(1), 15-26.

[25] Golledge, R. G. 2002. The nature of geographic knowledge. Annals of the Association of American Geographers 92 (1): 1-14.

[26] Gersmehl, P. 2005. Teaching Geography. New York: The Guilford Press.

[27] Idhawati, Marthalina. (2015). Comparison of spatial thinking levels between GIS and non-GIS students in understanding geographical space. Tesis. The Netherland: Wegeningen University

[28] Jeong Jo, Jung Eun Hong \& Kanika Verma (2016): Facilitating Spatial Thinking in World Geography Using Web-Based GIS, Journal of Geography in Higher Education: University Of Adelaide Libraries. 